\title{
Kafka and Legal Critique
}

Roberto Buonamano*

Kafka's preoccupation with the law and legal institutions within his fictional writings has always been a particularly fecund source of ideas for legal and political philosophy. Notwithstanding the justifiable emphasis on the historical and biographical situation of Kafka’s literary texts in jurisprudential commentary, those texts may also serve a valuable, autonomous function as a form of legal critique that supplements the doctrinal approaches of conventional legal theory. With this context in mind, the article presents a critical reading of three dominant juridical themes in Kafka's fiction: the relationship between slander and guilt; the significance of judgment over justice in the legal process; and, the association of necessity and immanence in the constitution of the legal subject. It seeks to demonstrate the specific contributions to legal critique of the rhetorical, structural and aesthetic elements of Kafka’s fictional treatment of law and legal authority.

“Reading” Kafka has become a precarious undertaking within literary criticism. At least since Walter Benjamin’s 1938 review of Max Brod's biography on Kafka, ${ }^{1}$ there has been continuous admonition of the perils of overinterpretation in Kafka scholarship, understood both in the sense of an excessive reliance on analogical similarity, ${ }^{2}$ and more broadly of

\footnotetext{
${ }^{*}$ Lecturer, Faculty of Law, University of Technology Sydney

${ }^{1}$ Benjamin (2002a), pp 317-21.

2 'In a universe dominated by the logic of similarity (and cosmic sympathy) the interpreter has the right and duty to suspect that what one believed to be the meaning of a sign is in fact the sign for a further meaning:' Eco (1991), p 164.
} 
interpreting through the lens of doctrinal paradigms (whether psychological, metaphysical, theological or socio-political). It is often remarked that Kafka's unique writing techniques have set the trap for the interpreter entering this patulous, semiotic field - the architectural manipulation of structure, the precision and economy of the prose, the anonymity of characters and places, the pedestrian dialogues that seem to herald more significant events, among others. Moreover, the burgeoning biographical corpus, much of it derivative of the autobiographical, has raised the stakes in this veritable battlefield between literal and metaphorical readings (and the many species in between), encouraged along by Kafka's intensely self-reflective stance on writing - witness, for example, the many allusions to the tormented, even demonic, condition of the writer in his diaries and letters. Yet, as Roberto Calasso intuits, “It's awkward to speak of symbols in Kafka, because Kafka experienced everything as symbol,"3 it would seem to be a futile, if not unjust, gesture to introduce symbolic significance to writing that arguably seeks its own escape from the pervasiveness of a deeply symbolic existence.

In this context, and out of an interest in allowing Kafka's texts to speak for themselves, the article's approach is to engage in a reading of Kafka's writings that demonstrates the specific ways in which the rhetorical, structural and aesthetic elements of his fictional treatment of law and legal authority have contributed to legal critique. Utilising and developing some of the ideas of his more sensitive interpreters, we shall examine three dominant conceptual strands in Kafka's account of juridical power. Firstly, Kafka's subversion of the function of guilt in legal responsibility, understood in terms of Agamben's contention of the trial as a process of self-slander. Secondly, Kafka's critique of the formalistic aspects of legal positivism, which reveals the law's preoccupation with process and judgment rather than guilt, and suggests that the possibility of justice must be perceived

\footnotetext{
${ }^{3}$ Calasso (2005), p 118.
} 
through an understanding of the self-contradiction of freedom and the conflation of legal and moral responsibility. Thirdly, the necessity and immanence of the legal order - especially manifest in the recurring relation between physical and symbolic violence - and the significance of the ontological division of the human and inhuman (a crucial influence on Agamben’s biopolitical thesis) for legal subjectivity.

\section{A. Slander and Guilt}

Giorgio Agamben's suggestion of the significance of the concept of slander within The Trial is worthy of investigation, if only because it opens the text to a reading that eschews the conventional treatment of guilt, responsibility and interiority normally associated with its protagonist's confrontation with the seemingly intractable and impenetrable legal system. As he notes, the doctrine of kalumnia in Roman criminal procedure provided as punishment for the making of a false accusation the branding of the initial " $K$ " on the forehead of the Kalumniator ${ }^{4}$ - this branding of infamy is referred to by Cicero and attested in various Roman law sources. ${ }^{5}$ According to those sources, "A lex Remmia set the rule that a calumniator was to be tried before the same tribunal (quaestio) before which he had prosecuted the innocent accused.” ${ }^{6}$ That Josef K. represents the kalumniator, thus simultaneously the innocent accused and the false accuser, reconfigures the principle causa in The Trial as a proceeding for self-slander. The trial, then, exists only in relation to-as a

\footnotetext{
${ }^{4}$ Agamben (2011), p 20.

5 'A man is innocent. But although he is free from guilt he is not free from suspicion...if you act in such a way as to accuse a man of having murdered his father, without being able to say why or how; and if you are only barking without any ground for suspicion...if I know these judges well, they will so firmly affix to your heads that letter to which you are so hostile that you hate all the Calends too, that you shall hereafter be able to accuse no one but your own fortunes': Cicero, pro Sext. Rosc. Amerino, c20 (1903); 'A party guilty of calumny is also branded with infamy, if judgment is rendered against him on that account’: Justinian, D. 3.6 (1932), p 7.

${ }^{6}$ Berger (1991), p 378.
} 
dependency but also its justification - the capacity of the accused, being convinced of his own innocence, to slander himself and thereby render himself guilty. The narrative is initiated with the mere revelation of an accusation, a slander, against K., an accusation whose author is never revealed, while it is $\mathrm{K}$. who presumes to be under arrest when confronted by the intruders, and who presents himself to the court, already marked as an accused. In that sense, K. constructs the particular case against himself as much as he is its subject. For Agamben, Kafka's point of departure is precisely the premise that "Every man initiates a slanderous trial against himself," that "guilt does not exist—or rather, guilt is nothing other than self-slander, which consists in accusing oneself of a non-existent guilt." ${ }^{7}$ Josef K.'s anxiety and preoccupation with the accusation, and indeed with the authorities which implicitly legitimise it, eludes his own crucial involvement in the legal process, just as every individual, far from “underpinning his existence with retrospective justifications," in actual fact erects his life on his justifications. ${ }^{8}$

If the function of the trial is not the determination of innocence and guilt but the treatment of self-slander, the law can be nothing other than the accusation itself. "The slanderous trial is a case where there is no case, where being indicted is the indictment itself." 9 This is implicit in the statements of those advising K., external to his predicament: his uncle says as much when he resignedly invokes the adage that such trials are lost from the start, as does the prison chaplain who, prior to professing himself to be in the service of the court, concedes that "the proceedings gradually merge into the judgment." ${ }^{10}$ Indeed, in his final moment, an ambiguous moment of either relative lucidity or credulity, K. questions—in

\footnotetext{
${ }^{7}$ Agamben (2011), p 21.

${ }^{8}$ Kafka (1991), p 52.

${ }^{9}$ Agamben (2011), p 24.

${ }^{10}$ Kafka (1998), p 213.
} 
apparent rhetoric but lacking any rhetorical intent- the existence of the judge he had never seen and the high court he had never reached. The illusory nature of the court as an institution is raised as a possibility precisely at the moment when the farcical spectacle of the execution traverses the point beyond which logic can function, where K.'s assurance in the reliability of reason is lost. As Agamben suggests, in Kafka the formal character of the law is remarkable for its lack of content, but on this count it is all the more pervasive: "the existence and the very body of Joseph K. ultimately coincide with the Trial; they become the Trial.»11

In a sense, self-accusation evades the attribution of guilt, but it does so on the pretext that truth itself is called into question. In this light, the interpretation of the elusive incipit ${ }^{12}$ to The Trial becomes a crucial philological issue: to what extent does the statement purport to reveal the relative guilt or innocence of K.? Remarking on the significance of a literal interpretation, Davide Stimilli associates the fact of a slander with the notion of innocence, renouncing (in sympathy with Orson Welles) the metaphysical Christian notion of guilt at birth. ${ }^{13}$ For Welles, the significance of the theme of guilt in The Trial is to call into question particular attitudes to innocence and guilt, as distinct from their attribution as facts. ${ }^{14}$ Though no doubt a compelling view, such an approach presupposes a certain security in a "literal" reading, which is far from obvious given the divergent approaches among the translators. In his Translator's Preface to The Trial, Breon Mitchell argues that previous English translations have opted for terminology which unequivocally suggests K.’s innocence-“without having

\footnotetext{
${ }^{11}$ Agamben (1998), p 53.

${ }^{12}$ In Breon Mitchell’s translation, 'Someone must have slandered Josef K., for one morning, without having done anything truly wrong, he was arrested’: Kafka (1998a), p 3.

${ }^{13}$ Stimilli (2012), p 107.

14 'The point is not whether he's guilty or innocent. It's an attitude towards guilt and innocencethat's the point of the story. Because what is guilt? The guilt of what?': Welles and Bogdanovich (1993), p 286.
} 
done anything wrong”-whereas the German syntax and the introspective nature of the narration would suggest that the veracity of K.'s observation is in doubt: “To claim that K. has done nothing 'Böses' is both more and less than to claim he has done nothing wrong. Josef K. has done nothing truly wrong, at least in his own eyes." ${ }^{15}$ Whatever the merit of this view, it does draw out the underlying ambiguity of the purportedly false accusation that is believed to have initiated the trial process, and, more to the point, the sense in which the individual accused is responsible to the law (in his own collusion) as well as before it. It is decisive that the thought of the trial should pervade K.'s consciousness; lacking knowledge of the charge and its basis, he must persistently account for his presence as an accused, which, in some respects, wholly instructs his relationship to the law via the obscurant court and its perversely officious representatives. K.’s indifference to being represented and scepticism of his lawyer's ability to penetrate the court system are reflected in the private and inscrutable nature of the judicial process. It cannot be overlooked that the proceedings are not public, and yet the fact of the accusation against $\mathrm{K}$. is known to others; that the court records and writ of indictment are not accessible to the accused, and yet the gravity of the charges is presented as given, manifest in the reactions of K’s uncle and his lawyer (the former laments the disrepute to the family name that such a serious predicament entails, while the latter questions whether his strength is "equal to this most difficult of tasks"16).

In a diary entry Kafka comments on the shared fate of the protagonists of his first two novels: "Rossman and K., the innocent and the guilty, both executed without distinction in the end, the guilty one with a gentler hand, more pushed aside than struck down." ${ }^{17}$ We cannot assume that Kafka's reference to $\mathrm{K}$. as guilty is a revelation of authorial intent; it may

\footnotetext{
${ }^{15}$ Kafka (1998a), xviii-xix.

${ }^{16}$ Kafka (1998a), p 100.

${ }^{17}$ Kafka (1976), pp 343-44.
} 
be no more than a reflection of the fact that the narrative revolves around the slanderous presumption of guilt from which K. never manages to extricate himself. In any case, this singular rumination offers a glimpse of how Kafka may have perceived the irony in K.s predicament: the accusation, as presumption of guilt, is all that stands between K.'s innocence and guilt, which is as much to say that the consequences of each are indistinguishable, that the innocence-guilt opposition is not actually determinative of judgment. In effect, the slander has set in train a juridical process in which the designators “innocence” and "guilt” are no longer meaningful. The slander, as accusation, is the causa, that which indicts, or to be precise, the indictment itself, with the accused as the object (cosa, thing) of the indictment; ${ }^{18}$ the legal process, then, follows from and absorbs the accusation, the truth of which no longer bears relation to the attribution of guilt.

That the narrative commences with a speculation, the veracity of which becomes increasingly marginal to the events that unfold, lends some significance to the subjective and parochial tenor of K's narratorial perspective. ${ }^{19}$ The truth of the accusation, thus the question of K.'s innocence or guilt, occupies a comparatively small stage, and is always subverted by logistical, often pedantic, preoccupations filtered through K's self-consciousness and instructed by his sensibility for order. In the opening arrest scene, the guards, who make a point of their inferior station and meagre knowledge of their department and its procedures, nonetheless understand that their functions are guided by the legal premise that the Court, rather than seeking out guilt from the general population, instead is attracted by guilt. In a

\footnotetext{
${ }^{18}$ Agamben (2011), p 23.

19 'Kafka's use of the subjunctive hätte in the opening sentence has huge implications for the rest of the novel. It suggests that K.'s innocence is not an objective fact but a subjective claim, possibly made by K. himself': Duttlinger (2013), p 58. We get a sense of the inherent susceptibility of this subjective viewpoint from the character sketch of a 'Joseph K.' in a diary entry of 29 July 1914, in which K., accused by his employer of theft, declares his innocence ('It's a mistake or a slander!') before conceding, somewhat perplexedly, his commission of the crime: Kafka (1976), pp 297-298.
} 
similar vein, the merchant Block will refer to the superstitious belief that the outcome of the trial can be predicted from the defendant's face, an imminent conviction being intuited in K's case by the tired and distracted people waiting in the court. This apparent reversal of causation-the law passively connecting itself to a pre-established guilt-imposes upon K. the duty of actively engaging with the accusation, one which he insouciantly evades, but also which comes to dominate his daily life. K.'s response, alerting to his ignorance of the law and in a futile attempt to gain a strategic advantage over his interlocutors, establishes a pattern that marks his indolent approach to the case against him. Later, K.'s uncle, reproaching K. for his apparent indifference, alludes to the foregone conclusion of guilt that passivity breeds: "that's not how an innocent man acts who still has his strength." ${ }^{20}$ Indeed, K. himself acknowledges that the truth of the accusation is of subsidiary importance, actually irrelevant, to the crucial issues: the identity of the accuser and the authorities animating the proceedings. The inspector's retort reaffirms the subjective and tenuous basis of the truth of the slander: in the first place, the very existence of an accusation remains a supposition of K.'s invention, of which the lower-level official cannot presume to know; in the second place, K's belief in or protestation of innocence could only serve to negatively influence the inferences to be drawn from his behaviour, which, impliedly, would form the central basis of the Court's assessment. Throughout these early scenes there is little indication that $\mathrm{K}$. is preoccupied with the injustice of the slander, at least to the extent that it would transcend the sense of shame and humiliation produced by the fact of the allegation and the mode of its delivery. Certainly, any such concerns are put paid to not long after the meeting with the lawyer, when K. exhorts himself to move beyond the initial contempt displayed for the trial and to adopt a more strategic approach to his defence, resolving "to reject the notion of any possible guilt right

\footnotetext{
${ }^{20}$ Kafka (1998a), p 92.
} 
from the start." ${ }^{21}$ We might suggest, then, that the starting point for The Trial, and for understanding the significance of its opening, is the subversion of this "a prioriness of guilt, ${ }^{22}$ its interiority and its necessary connection with the law.

Milan Kundera suggests that Kafka's ironical treatment of "guilt," in the form of the inducement of guilt, may be mapped through the character of $\mathrm{K}$. in accordance with five stages. In the first, “acting guilty without being so” introduces a humiliating element which K. struggles in futility to overcome. In the second, K.'s stance of superiority before the examining magistrate, leading to his refusal to accede to an interrogation, reveals itself as mere pretence when he finds it to have been taken seriously and proceeds to seek out another audience with the court. In the third, the trial is socialized: "Society has already adopted the accusation and added the weight of its tacit approval (or its nondisagreement).” The fourth sees K. searching for the crime himself, and within himself, to ratify the accusation whose truth has never been questioned. The fifth stage coincides with the supposed final scene: K.'s identification with his executioner. ${ }^{23}$ It is at this point that K.'s resolve to maintain a sense of dignity (equated with being calm and analytical) in order to see the trial through to the end on his own terms, ironically leads to cooperation and compliance with his escorts, even active assistance in evading the policemen, while the inability to fulfil his duty to seize the knife and use it upon himself resonates with the shame which inevitably outlives him.

Of course, it cannot be ignored that the staging of the final scenes bears no resemblance to the conventional formalities of a State-sponsored execution. K., in solemn dress and expectant, receives the guests whose visit had not been heralded. The

\footnotetext{
${ }^{21}$ The passage continues: 'There was no guilt. The trial was no different than a major business deal...in which, as was customary, various dangers lurked that must be avoided': Kafka (1998a), p 125 .

${ }^{22}$ Deleuze and Guattari, (1986), p 43.

${ }^{23}$ Kundera (2001), pp 206-11.
} 
"executioners," in their peculiar attire of frock coats and top hats, never reveal their status, functions or purpose, while their clumsy manner and comic appearance conjure the image of "old supporting actors" rather than officers of the court. In the end, it is neither the court nor the executioners who pronounce the verdict - the verdict is K.’s alone, which the men lean in towards his face to observe. There is good reason to consider the final scene as "more an act of torture gone awry than an execution." ${ }^{24}$ Viewed in this light, there is an unmistakable parallel to the events in the short story In the Penal Colony. The condemned man, knowing neither the fact of being sentenced nor the nature of the sentence, is to be executed via a machine whose function is to inscribe the violated law into his flesh until he is able to decipher the text. In principle, the harrow and its controlling scriber operate as an instrument of torture, with judgment complete only once the condemned man's wounds reveal to him the truth of his transgression. In the end, however, the mechanical process disintegrates, and the torture of the officer (who has replaced the accused man as the instrument's subject) gives way to his murder. Neither has the truth being deciphered, nor justice being carried out, while the intrinsic principle that "guilt is invariably beyond doubt" finds its contorted application in the facial expression on the officer's corpse - "It was just as it had been in life, with no sign of the promised deliverance."25

Here, punishment functions according to a different logic. No longer tied to guilt, it represents a dual movement. On the one hand, it effects the law's subjectification of the individual through the process of producing judgment; thus, punishment fulfils the singular requirement of judgment, the conflation of the legal process with the sentence. On the other hand, punishment appears as the 'last machination of the machine of necessity the law has

\footnotetext{
${ }^{24}$ Agamben (2011), p 29.

${ }^{25}$ Kafka (1981), pp 155, 176.
} 
become, ${ }^{26}$ and it is precisely in the necessity of the legal order that the question of justice assumes a marginal role. We shall consider each of these themes in turn.

\section{B. Between Justice and Judgment}

"And yet in the darkness he now sees a radiance that streams forth inextinguishably from the door of the Law.”27

Many of Kafka's references to law and legal authority are framed by spatial metaphors. The use of spatial imagery goes beyond mere context and aesthetics; it is also strategic in a critical sense. We can observe this in a couple of ways. Firstly, the spaces in which the protagonists find themselves often resist conventional depictions and associations - for example, the official and bureaucratic merge with the domiciliary - producing a disorienting effect for both the protagonist and the reader, and challenging any assumed situational certainty. In the short story Advocates the first-person narrator is seen wandering through labyrinthine corridors: narrow, austerely vaulted and sparsely decorated, seemingly created for profound silence, more akin to a library or museum than the law courts, but also sullied by the large, aproned bodies of the old women who incessantly come and go. At first glance, this is an incongruous place in which to seek advocates; but it is precisely the informal, arbitrary elements of the law, within which "all is accusation, advocacy and verdict," ${ }^{28}$ which necessitate the intervention of advocates that should be found anywhere, especially outside of the official setting. In a similar vein, the sites of authority in The Trial remain indistinct from the familiar, parochial world, creating an ambivalence that presumedly unsettles K.. The inspector who formally informs $\mathrm{K}$. of his arrest sets up office in the bedroom of a fellow

\footnotetext{
${ }^{26}$ Glen (2007), p 63.

${ }^{27}$ Kafka (1998a), p 216.

${ }^{28}$ Kafka (1971), p 498.
} 
lodger within the boardinghouse, a white blouse hanging from the window, the nightstand utilised as a desk. The offices of the court of inquiry before which K.'s initial interrogation is to take place are on the top floor of a non-descript building among tall, grey apartment houses in a poor residential area. The attic-like room into which $\mathrm{K}$. is ushered by a woman washing diapers in the antechamber is hazy and dark, crowded with men in formal black coats and a gallery of shabbily-dressed people. Upon returning to the court room on the following Sunday, he discovers that the offices, now characterised by a "sordid emptiness," also serve as the living quarters of the washerwoman and her husband, a court usher, when the court is not in session. The old, dusty and decrepit books sitting on the table that had been used by the examining magistrate suggest salacious reading material rather than legal texts. Even the studio of the painter Titorelli, a miserable, claustrophobic room furnished only with a bed and easel, is part of the court's offices, for "There are law court offices in practically every attic.”29 In these depictions, the public, ceremonial, sanctioned spaces one associates with the magisterial elements of legal authority are instead represented by confined, slatternly, even indecent, domestic spaces. Just as the question of innocence cannot be discerned through a legal lens, since guilt is already absorbed by the slanderous accusation, it is not possible to distinguish between what does and does not belong to the realm of the law, since the judicial authorities appear omnipresent - a corporeal, mundane and sordid presence - though ultimately elusive.

In another sense, Kafka portrays the individual's relation to the law in terms of a spatial distance or divide that cannot be exhausted or breached. This is achieved through the idea of a repetitive, endless striving to reach a destination that is in any case uncertain. In Advocates the corridors merely lead to further corridors, with more flights of stairs leading to

\footnotetext{
${ }^{29}$ Kafka (1998a), p 164.
} 
more floors - “As long as you don't stop climbing, the stairs won’t end.”30 Similarly, the parable recounted in The Great Wall of China $^{31}$ speaks of a messenger entrusted with a message of incomparable importance by the dying Emperor, but in order deliver that message the messenger would need to cross the palace, descend stairs and traverse the courts, only to find a second outer palace and more stairs and courts, leading to another set, and so on, a task that would consume thousands of years. Even if reaching the outermost gate, the messenger would then be confronted with the imperial capital, whose density no one could possibly penetrate. However, it is in the legend recounted by the priest in the Cathedral chapter of The Trial that we come across the most developed form of this metaphor. Its first three words, "Before the Law," set up a spatial relationship between the man from the country and the Law to which he futilely seeks admittance. It is a relationship defined by a series of obstructions or limitations. First, the man is only ever before the law, never within or outside. The law is treated simultaneously as a place to which one desires access and a beyond inscribed with the impossibility of a traverse. Thus, the man from the country is in a strange and paradoxical situation "where from the moment he wants to enter in the law, he is not there. In order not to transgress the law, he has to remain in the immobile situation before the law." 32 Second, the only true interaction between the man and the law is through the doorkeeper who forbids entry. The man exhausts his days with his entreaties towards and study of the doorkeeper, but the doorkeeper, whose singularity lies in his indifference, merely fulfils his duty, while all of the assumptions about the law (its universal accessibility, that all strive to reach it, that no one else has requested admittance) are of the man's own making. Indeed, that the entrance was meant solely for the man from the country implies that the

\footnotetext{
${ }^{30}$ Kafka (1971), p 499.

${ }^{31}$ Kafka (1971), pp 275-76.

${ }^{32}$ Cixous (1991), p 30.
} 
existence of the doorkeeper is also entirely dependent on the man's desire for access. Third, the entrance to the law is guarded by a potentially interminable number of doorkeepers of increasing power, the sight alone of the third doorkeeper being unbearable. This echoes the painter's distinction between the judges on the lowest levels, which are known but do not have the power to grant a final acquittal, with those of the highest court, in which the power resides but which are totally inaccessible to everyone. Again, the image of an incessantly and endlessly protracted path suggests the ultimate elusiveness of the law, without diminishing the very possibility of the task to which both the entrance and its doorkeeper attest. Hence the necessity of the man's relationship to the law - the desire for admittance is as perennial as the temporal and spatial distance to that which lies beyond the entrance.

In essence, the law is presented through the aporetic relation between an exterior and interior. It is aporetic in a conceptual sense, since the only certainty that exists is the space between the two, within which the man from the country is perpetually suspended. Both the man and the doorkeeper, albeit differentially, may be deceived as to whether there is anything beyond the entrance, thus whether there is an interior at all. The only experience which the man has of what exists beyond the door is the "radiance" that pierces the darkness that has enveloped him, while the simpleminded doorkeeper may not in fact know the interior of the law, merely "the path he constantly patrols back and forth before it." 33 As Cixous suggests, the absence of an interior is the law's secret: there is no material inside, for the law that prohibits is also itself prohibited. The "monstrous opening without inside" renders the law both "a step and its annulment;" the entrance is nothing more than the step the man did not take. ${ }^{34}$ Such an impasse can only be escaped through the question of the origin of the law,

\footnotetext{
${ }^{33}$ Kafka (1998a), p 220.

${ }^{34}$ Cixous (1991), pp 33-34.
} 
defeating the assumption that it has always existed. It is this question of the law's origin and by corollary, of the possibility of justice - which seems to recur within Kafka's texts.

The question is also taken up in the parable The Problem of Our Laws, describing a society whose laws are the privy and privilege of a select group of governing nobles. The problem to which the title refers is predicated upon the fact that the laws are not generally known. In turn, they are sustained by a number of presumptions: that the laws are ancient, thus inherently protected by a veritable tradition; that the laws are "scrupulously administered;" that the nobles have no cause to interpret the laws out of personal interest inimical to the general population since from the beginning they were made to the advantage of those to whom they were entrusted; and finally, that the laws actually exist. It appears, then, that the question "who doubts the wisdom of the ancient laws?" 35 is doubly rhetorical: the wisdom of ancient laws cannot be doubted, administered and interpreted as they are by those who stand above them, but it is this very characteristic which ultimately remains in doubt. Neither the popular belief that the laws are a mystery exclusively confided to the nobility, nor the opposing, marginally-held view that the laws do not actually exist, can remove the paradox produced by the fact that any repudiation of belief in the legitimacy of the laws - a necessary task in order to gain knowledge and control of the laws and avoid arbitrary rule - would entail a repudiation of the "sole visible and indubitable law" which binds the society, the nobility itself.

There is a cogent argument for interpreting these parables as a critique of the formalistic elements of legal positivism, at least of the type found in early twentieth-century Austro-German jurisprudence. ${ }^{36}$ "The text is immutable" the priest declares, while the

\footnotetext{
${ }^{35}$ Kafka (1971), p 482.

${ }^{36}$ On a biographical note, Arnold Heidsieck suggests the influence upon Kafka of the ideas of the German legal philosopher Oskar Kraus, who 'maintained that both jurisprudence and practical adjudication must seek a balance between literal adherence to codified civil law and the constant
} 
narrator in Advocates surmises that life would not be possible were judgment not passed in accordance with law: "one must have confidence that the court allows the majesty of the law its full scope, for this is its sole duty," ${ }^{37}$ which is as much to say that it is crucial to have faith in "the nobility and its right to go on living," 38 for the alternative would be to deprive oneself of the only certainty that law can offer. The illusoriness of legal positivism derives from the fact that, within its own terms, legal legitimacy rests upon constructed authority. Yet, authority, the foundation and basis for positing law, is by its very definition without foundation, resting upon no authority other than itself. ${ }^{39}$ Any attempt to rationalise the legitimacy of laws based on a positivist paradigm inevitably runs up against this axiomatic principle. In Kafka's texts legal positivism's claim to authenticity is counterposed to the fundamentally deceptive nature of this self-rationalised legitimacy. The doorkeeper, the law's agent, as much as the man from the country, stands in ignorance of the law; each in his own way is separated from the law and exists in a state of deception - the man cannot enter though the entrance was meant solely for him, while the doorkeeper is bound to his post though his duty is no more than an empty formality. Neither has access to the law, and neither can do anything but stand before it - a predicament reminiscent of that of the poet in Hölderlin's poem Timidity: "nothing awaits him but motionless existence, complete passivity, which is the essence of the courageous man - nothing except to surrender himself wholly to

\footnotetext{
${ }^{37}$ Kafka (1971), p 498.

${ }^{38}$ Kafka (1971) p 483.

${ }^{39}$ Derrida (2002), p 242.
} 
relationship.”40 This remains the inescapable truth of the law’s authority, but an authority based on what?

Minkkinen proposes a reading sympathetic with Nietzsche's thesis on the 'will to power'. Given that the very notion of an authority to create laws assumes a higher rule of law that both legitimates the authority and conditions its use, the function of legitimacy is undermined by its own promise. With Nietzsche's reversal of the relationship between a command and its legitimacy, the rule of law and justice, far from being foundational precepts that shape the quality of laws, are only ever the reflections of a commanding will, the expressions of the will to power. ${ }^{41}$ That justice is subjected to and conditioned by the positing of laws implies, beyond the apparent and facile reversal of roles, a fundamental rethinking of the conceptual relationship between justice and judgment.

As Derrida notes, "To be invested with its categorical authority, the law must be without history, genesis, or any possible derivation.” ${ }^{42}$ With legal positivism the question of the law's origin is chronically displaced in favour of a recurring performative act: the law's legitimacy is proclaimed and reified by the very act of the law being in force, and through each act by which it declares right. The Problem of Our Laws suggests that laws based on constructed authority create and are nourished by tradition, a tradition of interpretation and application. Thus, while it can be said that history comes into the service of positive law, it does so as an aid to interpretation (and corresponding reification) rather than as a function of its derivation, since the law's claim to legitimacy is fundamentally ahistorical. When the priest states the opinion that no one has the right to pass judgment on the doorkeeper, his being the servant of the law and thus detached from human judgment, it is implicit that the

\footnotetext{
${ }^{40}$ Benjamin (2002a), p 34.

${ }^{41}$ Minkkinen (1994), pp 359-360.

${ }^{42}$ Derrida (1992), p 191.
} 
divide between man and the law, which ultimately furnishes the latter with immunity from scrutiny of its foundation, supplies legal positivism with the basis for its rationality.

What, then, can be made of the inextinguishable light from the door? Does Kafka suggest that justice through the law may be possible? Gunther Teubner offers two possible readings: one would situate justice in the experience of the man before the doorkeeper, a "patient, self-tormenting, humiliating confrontation;" the other would locate it within the "collective imagination of the legal discourse" that seeks to penetrate through to the law. Should the light be seen as an illumination of law that connotes the possibility of justice, however refracted and slight, as an inextinguishable force, evoking an enduring biblical metaphor, or does the recognition of the possibility of the man's eyes being deceived imply that it is all simply an illusion, that the endless waiting and the singularity of the entrance which is to be closed merely conceal the law's emptiness? The latter would preclude any instrumental value to law as a means of achieving justice. As Robert Bolt has Thomas More declare, "The law is not a 'light' for you or any man to see by; the law is not an instrument of any kind." 43 Teubner is surely correct to conclude that ambivalence on this question is unavoidable, lacking as we do the criteria for distinguishing between a collective imagination of justice and a collective self-deception. ${ }^{44}$ What remains clear, though, is that the passivity implicated in being before the law is marked by a contradictory set of duties, to obey the law (since entry is forbidden) and to breach it (in order to access), a "double bind" that provides the man with absolute freedom and at the same time "entangles him in permanent guilt." 45 "[I]t's often better to be in chains than to be free," ${ }^{46} \mathrm{~K}$.'s lawyer explains, alluding to the

\footnotetext{
${ }^{43}$ Bolt (2013), p 97.

${ }^{44}$ Teubner (2013), p 420.

${ }^{45}$ Teubner (2013), p 414.

${ }^{46}$ Kafka (1998a), p 190.
} 
oppressive nature of the freedom that is the condition of the accused. Contrary to the assumptions of liberal ideology, it is the law that creates freedom rather than law being produced by the exercise of free will. The freedom that law creates is ipso facto subject to the law, a juridical construct or fiction, if you will, and thus inherently circumscribed. As the nonhuman narrator in A Report for an Academy reflects, men are often betrayed or duped by the idea of freedom; "as freedom is among the most sublime of feelings, so is the corresponding illusion among the most sublime." ${ }^{47}$ The illusion of freedom is also a thematic undercurrent in The Castle, defining K.'s relationship with the authorities. As the Castle itself becomes increasingly tenebrous and chimerical to K. (its contours "already beginning to dissolve”), his quest to access and receive recognition of his purpose from its officials leaves him waiting in vain, and while his right to stay in an otherwise forbidden place provides him with a newfound freedom, he feels "as if there were nothing more senseless, nothing more desperate, than this freedom, this waiting, this invulnerability." 48 The legal space of freedom is created precisely through the paradox of prohibition, and therefore is annulled by the contradiction of self-restraint: you are free to do so, but with your freedom you must ensure that you do not. Derrida expresses it thus: "The law is prohibited. But this contradictory selfprohibition allows man the freedom of self-determination, even though this freedom cancels itself through the self-prohibition of entering the law." 49 If justice exists as potentiality, it is not obvious that for Kafka it is to be found in positive law and its institutions.

The essence of the trial is process, as the semantics of the German title for the novel (Der Process) suggest. And as is insinuated throughout the novel, the legal process is inexhaustible. The trial is not a set of proceedings that can ever be concluded, a position

\footnotetext{
${ }^{47}$ Kafka (1981), p 222.

${ }^{48}$ Kafka (1998b), pp 98, 106.

${ }^{49}$ Derrida (1992), p 204.
} 
which indeed may be reflected in the inconclusive character of Kafka’s "unfinished” novel. ${ }^{50}$ The painter makes this clear when he explains to $\mathrm{K}$. that the two possible outcomes of the trial - apparent acquittal and protraction - share the purpose of preventing a final determination, whether conviction or actual acquittal. Apparent acquittal is marked by the "ceaseless routine of the court offices," with the active file always susceptible to being resumed and initiating a further arrest and proceedings, while protraction, which stalls the case at its first instance, ensures that the interrogations and examinations will continue to be conducted without the promise of finality. ${ }^{51}$ We might suggest, then, that the relationship between law and judgment is at once teleological and homologous. In a teleological sense, the law is solely directed towards judgment, rather than justice or truth - "the ultimate aim of law is the production of a res judicata, in which the sentence becomes the substitute for the true and the just." ${ }^{52}$ By the same token, the protracted nature of the trial process places in doubt any conceptual divide between law and judgment. "[P]ostponement is the hope of the accused man only if the proceedings do not gradually turn into the judgment," 53 a hope which the priest disconcertingly quashes. This is the enigma of the law-judgment relation. The law serves to produce judgment, while judgment absorbs the trial process and fulfils itself only in perpetuity, as the very process of judging, without the possibility of deliverance. When the priest concludes that "The court wants nothing from you. It receives you when you come and dismisses you when you go," ${ }^{54}$ he is not merely confirming the painter's sober revelation of

\footnotetext{
50 'But as the trial, according to the author's own statement made by word of mouth, was never to get as far as the highest Court, in a certain sense the novel could never be terminated - that is to say, it could be prolonged into infinity:' Brod, 'Postscript to the First Edition’ in Kafka (1969), p 271.

${ }^{51}$ Kafka (1998a), p 161.

${ }^{52}$ Agamben (2008), p 18.

${ }^{53}$ Benjamin (1999), p 807.

${ }^{54}$ Kafka (1998a), p 224.
} 
the futility of seeking an actual acquittal (a delusive, if mystical, goal, as suggested by the final verdicts of past cases being accessible only through legends); he is also remarking that the juridical process, which begins with the accusation, inevitably ends with judgment, not as a means of establishing innocence or guilt, nor for the purpose of punishing transgressions, but as the end in itself. ${ }^{55}$ This, in a schematic sense, is the message behind the pictorial representation of Justice and the goddess of Victory combined in the same person. ${ }^{56}$ As Agamben goes on to explain, the self-referential nature of judgment has been disguised through the conceptual confusion between morality and law. The conventional understanding of responsibility as a radically moral idea that gives rise to the application of law in the pursuit of justice (as evidenced especially in the discourses surrounding the judgments in the Nuremberg trials) ignores the historical contamination of moral principles by juridical concepts. Responsibility, like guilt, is fundamentally a juridical rather than moral category it is tied to the notion of culpa or fault, the "imputability of damage," and thus properly belongs to the law rather than the subjective interiority of ethics. ${ }^{57}$

We have observed, through Kafka's parabolic representation of the law, that law operates at a purely formalistic level, and is ultimately lacking foundation; that legal positivism is irremediably marked by the relational absence of an interior. For Kafka, then, the possibility of justice is conditioned by the functional manifestation of the law as juridical process, in which the freedom necessary for the exercise of justice reveals itself as mere illusion. As Banaker notes, a paradox 'lies at the heart of the relationship between modern law, which strives towards generality and universality, and justice, which requires the

\footnotetext{
55 'One can even say that the whole punishment is in the judgment, that the action characteristic of punishment - incarceration, execution - matters only insofar as it is, so to speak, the carrying out of the judgment:' Satta, Il mistero del processo (Adelphi, Milan, 1994), p 26, cited in Agamben (2008), p 19.

${ }^{56}$ See Kafka (1998a), p 145.

${ }^{57}$ See Agamben (2008), pp 20-24.
} 
recognition of singularity and specificity. ${ }^{58}$ For Kafka, the paradox can be observed precisely in the law's functioning, where the non-rational aspects of the law are sustained by the inherent rationality of its process, thus the law's preoccupation with judgment. As we shall discover, this critique of law's formalism implicates, subjectively, a relation of necessity and immanence between the individual and the legal order, most lucidly depicted in the situational subjection of Kafka’s characters.

\section{Subjection, Necessity, Immanence}

A related theme in Kafka's legal references is that of the immanence and necessity of the legal order within which all of the characters circulate and to which they are inextricably bound. "Everything belongs to the court," ${ }^{59}$ the painter explains, and though said partly in jest, the idea resonates with the observations we have already made regarding the representation of the law's spatial presence in Kafka's stories. K.'s lawyer refers to the court and its proceedings as a "vast judicial organism" ${ }^{60}$ existing “in a state of eternal equilibrium," such that any disturbance would be compensated for in order for the organism to remain unchanged, if not rendered more resolute, vigilant and malicious. ${ }^{61}$ And the priest, in reference to the dignity to be accorded to the doorkeeper by virtue of his legal appointment, retorts that “you don't have to consider everything true, you just have to consider it necessary." ${ }^{2}$ The law speaks through and acts by necessity. If there is any degree of realisation or awakening on the part of $\mathrm{K}$. from his involvement in the legal process, it is

\footnotetext{
${ }^{58}$ Banakar (2010), p 480.

${ }^{59}$ Kafka (1998a), p 150.

${ }^{60}$ Similarly, in The Castle the official organization is described as 'a great living organization' whose most pronounced virtue is its seamlessness - Kafka (1998b), pp 265, 267.

${ }^{61}$ Kafka (1998a), p 119-120.

${ }^{62}$ Kafka (1998a), p 223.
} 
perhaps regarding this point. He appears to recognise that deception remains the law's modus operandi with his disconsolate reply that "Lies are made into a universal system," but it cannot be his final judgment for he is so overcome by weariness as to be unable to take in all of its consequences. ${ }^{63}$

According to Hannah Arendt, the law's deception is what mobilises the judicial machine for the sake of necessity, the latter defined by its sublimity and automatism. The priest, as prison chaplain, is the ultimate representative of this order: his defence of the system by way of a legend and its interpretations (a narrative form which, by definition, blurs the distinctions between myth and history, fable and fact), attests to his role as guardian of an order at once mystical and immanent, a role reminiscent of the archaic figure of the juristpriest in Roman and Medieval societies. His words "reveal the secret theology and the deep faith of bureaucrats to be a faith in necessity as such, and the bureaucrats end up as the functionaries of necessity." 64 The deception (the injustice, stigmatization and humiliation) of the man from the country - and in parallel, of K. himself - is "both denied and endlessly repeated because it is seen as 'necessary' for the order of the world." ${ }^{65}$ This is presented metaphorically in the progressive darkening of the cathedral, with K. effectively lost in the darkness.

The notion of subjection to a state or situation that is considered to be necessary resounds through many of Kafka's stories. The jackals in Jackals and Arabs move as though animated "at the dictate of a whip," the consequence of an ancient blood feud underwritten by ancient law. ${ }^{66}$ As with the secretive laws entrusted to the nobles in The Problem of Our Laws,

\footnotetext{
${ }^{63}$ Kafka (1998a), p 223.

${ }^{64}$ Arendt (2007), p 101.

${ }^{65}$ Casanova (2015), p 328.

${ }^{66}$ Kafka (1981), pp 196-197.
} 
or the laws that do not resemble any known to K. in The Trial, the ancient law, assuming the form of a canonical tradition, becomes an ineluctable social force that creates and justifies relations of subjection. Out of tradition necessity is born and its historical conditions forgotten. While the jackals attempt to extricate themselves from the feud by urging the European explorer to exterminate their foe, they ultimately remain bound to the chief Arab's whip, as though circus animals playing their part. "The point is to describe people who act as though 'under the law (Gesetz) of a whip' and perhaps, even, under the whip of a law." ${ }^{67}$ A similar dynamic can be gleaned from some of the interpersonal relationships in Kafka's stories. In The Metamorphosis, Gregor's unexplained transformation into a giant insect sees him endure incompassion and increasing cruelty by his family members, their final decision to rid themselves of him being fatefully accepted and even endorsed by Gregor: "The decision that he must disappear was one that he held to even more strongly than his sister, if that were possible.”68 Similarly, in The Judgment we witness the protagonist willingly subjecting himself to a verdict that seems inescapable. As Georg's interaction with his father gradually disintegrates into resentment and dubitable accusations against him, his father charts the inevitable course of his son's life, from "innocent child" to "devilish human being," ${ }^{69}$ before pronouncing his death sentence. Ironically, given that the son is destroyed not by the power and aggression wielded by his father but "by the emotional bond which ties him to [his] parents” and thereby eliminates resistance, ${ }^{70}$ Georg declares his love for his parents as he allows himself to fall into the water. Louis Begley notes, in relation to the fathers who kill or banish sons who transgress in Kafka's stories, that the sons do not fight

\footnotetext{
${ }^{67}$ Casanova (2015), p 298.

${ }^{68}$ Kafka (1971), p 160.

${ }^{69}$ Kafka (1971), p 113.

${ }^{70}$ Duttlinger (2013), p 32.
} 
back - "They do not all, like Georg, rush to become their own executioners, but, without exception, they submit to the punishment."71

There is a recurring connection between physical and symbolic violence in Kafka's texts. ${ }^{72}$ Even in a story such as In the Penal Colony, in which the description of physical violence is both prosaic and incisive, the spectre of symbolic domination and violence is pervasive. The colonial setting, the significance of military discipline to social order, the conflict between opposing ideologies in relation to the function and severity of punishment these elements of the narrative each contribute to an analysis of the nature of authority, legal tradition, judicial power and the culture of obedience. Of equal significance and effectiveness, however, is the device of the apparently disinterested foreigner, through whose objective lens much of the critique of the colonial penal system passes, to portray the more insidious forms of domination and submission. The traveller's antipathy towards the cruel punitive methods advocated by the zealous officer - "The injustice of the procedure and the inhumanity of the execution were beyond doubt $^{73}$ - is tempered by a soundly-reasoned reticence to intervene in the affairs of a country to which he does not belong. The traveller fails to stop the officer's self-imposed torture and execution, even as he witnesses the disintegration of the machine, but also actively prevents the soldier and the condemned man (now nominally free) from escaping their incarceration on the island. The distinguished foreigner's enlightened views on criminal justice and corresponding humane sentiment are overwhelmed by a concern, indeed a responsibility, to not disturb the order of things, to respect the extant system of authority despite its decay and impending transformation, just as he feels the power of an earlier age in the old colony's buildings notwithstanding their state

\footnotetext{
${ }^{71}$ Begley (2008), p 166.

${ }^{72}$ Casanov (2015), p 322.

${ }^{73}$ Kafka (1981), p 161.
} 
of disrepair. Despite the ideological differences, there is, in effect, a fundamental continuum among the condemned man (who submits to his punishment in ignorance), the officer (who submits to tradition by supporting the old commandant's legacy), and the traveller (who acquiesces in the barbaric injustice from the privileged perspective of the rational, dispassionate observer, proving himself to be just as powerless to resist as the others).

An analogous scene in The Trial has $\mathrm{K}$. rationalising his decision to ignore the requests for intervention from the guards who are to be punished as a consequence of K's report to the examining magistrate. The flogger's conviction that "their punishment is as just as it is inevitable” is effectively sanctioned through K.'s capitulation - though he is tormented by not having prevented the flogging - as the threat to his reputation from being observed in such a predicament convinces him that no one "could really demand such a sacrifice from him.”74 Once again, the question of justice is marginalised by the (historical) relations of power that situate individuals in seemingly inexorable conditions in which their compliance is a matter of course. ${ }^{75}$ Moreover, the law in Kafka's world "feeds on hierarchy and difference" while undermining the boundaries and distinctions that serve as their foundations. "[W]hat separates the holders of powers from their inferiors becomes blurred," such that "even the most deeply fallen can abruptly regain their terrible power, and in the same way, the accused can become the accuser."76

According to Calasso, the most persuasive gloss on the parable Before the Law is Kafka's own in the form of The Castle, ${ }^{77}$ pointing to the semblance between the man from the

\footnotetext{
${ }^{74}$ Kafka (1998a), pp 82, 85.

${ }^{75}$ Kafka expresses an analogous point when he reflects that 'life, because of its sheer power to convince, has no room in it for right and wrong...It is enough that the arrows fit exactly in the wounds that they have made:' Kafka (1976), p 402.

${ }^{76}$ Gaschè (2002), p 977.

${ }^{77}$ Calasso (2005), p 274.
} 
country's relationship to the Law and the visiting land surveyor's relationship to the Castle. While the law in The Trial functions by way of prohibitions and judicial procedures, and the Castle by way of regulations and administrative practices, they have in common the representation of power as immanence. This form of representation relies upon a particular conception of the law which owes little to either (juridical) sovereignty or (theological) transcendence. Indeed, within Kafka's fiction the law is never depicted as a system - which would implicate a structure or organisation based upon constitutive principles, including of rights and of justice - rather, the law is experienced through rules, and invariably via the agents entrusted with their application. Rules supplant the majestic (thus supra-juridical) elements of the law by a logic of regularity, process and administration:

Rules also suppress the rights which go along with the notion of law, and establish the reign of pure procedure which - a manifestation of technical competence, of sheer knowledge - invests everything, controls everything, submits every gesture to its administration, so that there is no longer any possibility of liberation, for one can no longer speak of oppression. ${ }^{78}$

Further, the relation of immanence connotes the state of being both intrinsic and omnipresent, but in a strategically quotidian sense. The power of the Castle lies with "the way it invades the lives of individuals even in their most intimate moments."79 In both The Trial and The Castle formal distinctions between the public, the official and the private spheres are constantly eroded. In the former, Josef $\mathrm{K}$. attempts in vain to maintain some separation of his private and business life from the official proceedings, whereas the court penetrates all aspects of his daily existence, and the law, in its realisation as judgment, ultimately affirms itself through the very body of K. In the latter, by contrast, $\mathrm{K}$. actively seeks to integrate his

\footnotetext{
${ }^{78}$ Blanchot (1995), p 144.

${ }^{79}$ Duttlinger (2013), p 99.
} 
life with that of the village (which is merely the property of the Castle) in his pursuit of an acknowledgment from the Castle authorities of his appointment and justification for his presence. In both cases, however, the power exercised by the authorities is coextensive with the lives of the individuals who are subject to it. For Kafka, the human is effaced by the immanence of power. The individuals that circulate around the court or the village only exist through their relationship to the authorities, and genuinely lack an autonomous identity. This is arguably reflected in the minimalistic portrayal of the characters, who are invariably abstract, incomplete and occasionally surreal. In this regard, Arendt suggests that the protagonists consider themselves distinct from society since their role is "utterly indeterminate," while the incidental characters “do not exhibit any psychological features because they simply do not exist outside of their roles, positions, and occupations." ${ }^{80}$ In a similar tone, Benjamin discerns in the activities of the assistants or messengers which populate Kafka's stories “the Law that reigns, in an oppressive and gloomy way, over this whole groups of creatures,” none of which has “firm inalienable outlines.”81

Kafka's effacement of the human becomes one of the points of departure for Agamben's thesis on the interrelationship between law and human (bare) life that characterises sovereign power. There are two main aspects to the logic of this thesis. The first concerns the ontology of the human being, which is radically divided between the human (speaking being, logos, subjectification) and the inhuman (living being, desubjectification). ${ }^{82}$ This division between the speaking being and the living being, the human and the animal, is

\footnotetext{
${ }^{80}$ Arendt (2007), p 102. Kafka's oblique mode of characterisation has also been examined from the perspective of outsider jurisprudence, reflecting the situational relations of individuals to the dominant legal apparatus, in place of more conventional subjective personas: see Litowitz (2002).

${ }^{81}$ Benjamin (1999), p 799.

${ }^{82}$ Agamben (2008), pp 133-135.
} 
the decisive political conflict in Western culture, and the basis for all other conflicts. ${ }^{83} \mathrm{We}$ can trace this ontology to Kafka's treatment of subjectivity. In his extensive menagerie of characters - including animals intruding into the human world (The Metamorphosis), animals co-existing with humans (Jackals and Arabs, A Report for an Academy) and animal narrators with human psychologies but circumscribed by their natural environment (Investigations of a Dog, The Burrow) - the differences between humanity and animality are neither fixed nor determinative. Moreover, the figures that submit to necessity, as an exercise of their paradoxical freedom, epitomise the contradiction of divided being: as subject, they embody both subjection and sovereignty; this double movement, of subjectification and desubjectification, is the fundamental condition of shame, the subject's becoming witness to its own oblivion as subject. ${ }^{84}$ Josef K.'s final words during his execution, “Like a dog!” aptly expresses the shame that will survive his annihilation. Agamben's Kafka is the writer who has done most to renounce the theodical concerns of guilt and freedom in favour of the redemptive figure of shame; as Salzani lucidly expresses it, 'Shame as a privileged - and revolutionary - opening to subjectivization and to the inner self, and thus as a possibility for a new, post-biopolitical ethics. ${ }^{85}$

The second concerns the politicisation of life through the state of exception: "Law that becomes indistinguishable from life in a real state of exception is confronted by life that, in a symmetrical but inverse gesture, is entirely transformed into law." ${ }^{86}$ The state of exception is one in which it is "impossible to distinguish transgression of the law from

\footnotetext{
${ }^{83}$ Agamben (2004), p 80.

${ }^{84}$ Agamben (2008), pp 106-107.

${ }^{85}$ Salzani (2013), p 269.

${ }^{86}$ Agamben (1998), p 55.
} 
execution of the law," where violation of the law and conformity with it coincide. ${ }^{87}$ This dilemma or paradox of the law may be observed in many aspects of the relationships between individuals and the authorities in Kafka's texts. Much of the way in which the court operates in The Trial may be classified as extra-legal or exceptional: indictments and evidence that are not made known, hearings that occur outside of formal processes, secret punishments in private, execution without verdict and judgment. Yet, there is never any doubt cast upon the legitimacy and legal force of these functions and acts, and all of the characters either fulfil their official roles dutifully or accept the validity of even seemingly arbitrary rules and practices. The exceptional becomes the norm by virtue of the "indistinguishability" between law and life. For Agamben, Kafka's law is the pure form of law that neither prescribes nor signifies, but remains in force, its very openness maintaining life in its grasp, as the man from the country remains paralysed before an open door destined for him. The sovereign relation that characterises the state of exception functions in accordance with the 'relation of inclusionary exclusion or exclusionary inclusion in which the law keeps life in its power by excluding life from law’s domain. ${ }^{88}$ Moreover, Agamben reads Kafka’s account of law as admitting the possibility of justice, not in the overturning or 'erasure' of law but in its 'deactivation and inactivity', the potential other uses of the law that are available beyond its formal suspension. ${ }^{89}$

\section{Literature as Legal Critique}

Though we have only presented a minor interrogation of a seemingly inexhaustible field, it is patent that the legacy of Kafka's writing - and the now vast interpretive canon surrounding it

\footnotetext{
${ }^{87}$ Agambem (1998), p 57.

${ }^{88}$ Salzani (2013), p 272.

${ }^{89}$ Agamben (2005), p 64.
} 
- for legal critique is significant. "Literature is the place of contradictions and disputations" Blanchot writes, ${ }^{90}$ and it is this pronounced feature which best explains the value of Kafka's juridico-political observations. Kafka's literary explorations of the law and its institutional manifestation in the lives of individuals offer an aesthetico-critical method with which to understand the ways in which the law functions and justifies itself through discourse. Such a method avoids some of the limitations of theoretical approaches to legal critique - by which is meant those seeking to establish a theory that accounts for law's rationality - precisely because it does not purport to explain the rational basis for the law, but instead challenges its assumed systematicity and questions what is at stake in this rationality. What renders it an especially useful, critical method is its ability to expose the reader to the paradoxes, inconsistencies and absence in the law through a direct engagement or experience with its “contradictions and disputations.” Within the constraints of academic disciplines, legal theory struggles to account for the non-rational elements of legal practice, or the "particular excesses of legal ambivalence" - by contrast, literature allows "the possibility for the paradoxes of the Law to be experienced."91

There is, perhaps, in Kafka a relationship of continuity between literature and legal critique. Each strives to express the inexpressible, the impossible. To be more precise, each confronts the limitation inherent in the fact that any use of language to understand how things are risks becoming the object of its analysis, from which there is no escape but merely an endless repetition. Literature is this struggle to grant language some significance without undermining the edifice that is thereby constructed. This may, in part, explain the "unfinished” status of many of Kafka's writings - rather than incomplete, they appear as interrupted, interrupted by the impossibility of completion. By the same logic, his main

\footnotetext{
${ }^{90}$ Blanchot (1995a), p 24.

${ }^{91}$ Teubner (2013), p 421.
} 
stories may be considered "fragments" (as is the totality of the work), a trait that renders "their reading unstable" though it is hardly accidental: "It is incorporated in the very meaning that it mutilates; it coincides with the representation of an absence that is neither tolerated nor rejected." ${ }^{92}$ Legal critique runs the same gauntlet. To understand the law, its existence, substance and modalities, demands an appreciation of the absence which it conceals; however, this absence cannot be expressed as an essential character of the law - the crucial task, which Kafka has taken up more assiduously than any other writer, is to offer a glimpse into the indeterminate, non-rational and paradoxical experience of being a legal subject.

\section{References}

Giorgio Agamben (1998) Homo Sacer: Sovereign Power and Bare Life, Stanford University Press.

Giorgio Agamben (2004) The Open: Man and Animal, Stanford University Press.

Giorgio Agamben (2005) State of Exception, University of Chicago Press.

Giorgio Agamben (2008) Remnants of Auschwitz: The Witness and the Archive, Zone Books.

Giorgio Agamben (2011) Nudities, Stanford University Press.

Hannah Arendt (2007) 'Franz Kafka, Appreciated Anew' in Susannah Young-ah Gottlieb (ed) Reflections on Literature and Culture, Stanford University Press.

Reza Banakar (2010) 'In Search of Heimat: A Note on Franz Kafka’s Concept of Law’22(3) Law \& Literature 463.

Louis Begley (2008) The Tremendous World I Have Inside My Head. Franz Kafka: A Bibliographical Essay, Atlas \& Co.

Walter Benjamin (1999) 'Franz Kafka: On the Tenth Anniversary of His Death' in Selected Writings Volume 2 1927-1934, The Belknap Press of Harvard University Press.

Walter Benjamin (2002a) 'Two Poems by Friedrich Hölderlin' in Selected Writings Volume 1 1913-1926, The Belknap Press of Harvard University Press.

Walter Benjamin (2002b) 'Review of Brod's Franz Kafka' in Selected Writings Volume 3 1935-1938, The Belknap Press of Harvard University Press.

\footnotetext{
${ }^{92}$ Blanchot (1995a), p 6.
} 
Adolf Berger (1991) Encylopedic Dictionary of Roman Law, American Philosophical Society.

Maurice Blanchot (1995a) The Work of Fire, Stanford University Press.

Maurice Blanchot (1995b) The Writing of the Disaster, University of Nebraska Press.

Robert Bolt (2013) A Man for All Seasons: A Play of Sir Thomas More, Bloomsbury.

Max Brod (1969) 'Postscript to the First Edition’ in Franz Kafka The Trial, Schocken Books.

Roberto Calasso (2005) K., Alfred A. Knopf.

Pascale Casanova (2015) Kafka, Angry Poet, Seagull Books.

M. Tullius Cicero (1903) The Orations of Marcus Tullius Cicero, George Bell \& Sons.

Helene Cixous (1991) Readings: The Poetics of Blanchot, Joyce, Kafka, Kleist, Lispector, and Tsvetayeva, of Minnesota Press.

Gilles Deleuze and Felix Guattari (1986) Kafka: Toward a Minor Literature, University of Minnesota Press.

Jacques Derrida (1992) 'Before the Law’ in Acts of Literature, Routledge.

Jacques Derrida (2002) 'Force of Law: The "Mystical Foundation of Authority"' in Acts of Religion, Routledge.

Carolin Duttlinger (2013) The Cambridge Introduction to Franz Kafka, Cambridge University Press.

Umberto Eco (1991) Interpretation and Overinterpretation: World, History, Texts' in Grethe B. Peterson (ed) The Tanner Lectures on Human Values, vol. 12, University of Utah Press.

Rodolphe Gaschè (2002) Kafka's Law: In the Field of Forces Between Judaism and Hellensim 117(5) MLN 971.

Patrick J. Glen (2007) 'The Deconstruction and Reification of Law in Franz Kafka's "Before the Law” and The Trial' 17(23) Southern California Interdisciplinary Law Journal 23.

Arnold Heidsieck (date unknown) 'The Fictional or Non-Fictional Uses of Administrative, Civil, and Criminal Law by Kafka and his Friends'

http://www.usc.edu/dept/LAS/german/track/heidsiec/KafkaLawsources/KafkaLawsources.pd f.

Justinian (1932) The Civil Law, including The Twelve Tables, The Institutes of Gaius, The Rules of Ulpian, The Opinions of Paulus, The Enactments of Justinian, and The Constitutions of Leo, The Central Trust Company.

Franz Kafka (1969) The Trial, Schocken Books. 
Franz Kafka (1971) The Complete Stories, Schocken Books.

Franz Kafka (1976) Diaries, 1910-1923, Schocken Books.

Franz Kafka (1981) Stories 1904-1924, Macdonald \& Co.

Franz Kafka (1991) The Blue Octavo Notebooks, Exact Change.

Franz Kafka (1998a) The Trial: A New Translation, Based on the Restored Text, Schocken Books.

Franz Kafka (1998b) The Castle: A New Translation, Based on the Restored Text, Schocken Books.

Milan Kundera (2001) Testaments Betrayed: An Essay in Nine Parts, Perennial.

Douglas Litowitz (2002) 'Franz Kafka’s Outsider Jurisprudence 27(1) Law and Social Inquiry 103.

Davide Stimilli (2012) 'Secrecy and Betrayal: On Kafka and Welles' 12(3) The New Centennial Review 91.

Panu Minkkinen (1994) 'The Radiance of Justice: On the Minor Jurisprudence of Franz Kafka’ 3 Social and Legal Studies 349.

Carlo Salzani (2013) 'In a Messianic Gesture: Agamben’s Kafka in Brendan Moran and Carlo Salzani (eds) Philosophy and Kafka, Lexington Books.

Gunther Teubner (2013) 'The Law before It is law: Franz Kafka on the (Im)possibility of Law’s Self-reflection’ 14(2) German Law Journal 405.

Orson Welles and Peter Bogdanovich (1993) This is Orson Welles, Harper Collins Publishers. 